\author{
Karin K. Flensner \\ University West
}

DOI: http://dx.doi.org/10.5617/adno.8347

\title{
Dealing with and teaching controversial issues - Teachers' pedagogical approaches to controversial issues in Religious Education and Social Studies
}

\begin{abstract}
What strategies do teachers use, in classroom practice, to handle issues highly contested in society? This article focuses on how the various Middle Eastern conflicts and related topics, theoretically framed as controversial issues, are dealt with in religious education and social studies classes. The aim is to analyse pedagogical approaches teachers applied in situations where topics associated with regional, cultural, and/or religious conflicts (e.g., migration, terrorism, radicalisation, xenophobia, anti-Semitism, and Islamophobia) were part of the teaching. What approaches were distinguishable in classroom practice? How did teachers reflect on this teaching? To examine these issues, ethnographic observations were made of religious education and civics classes at upper secondary schools in Sweden; follow-up interviews with teachers and students were also conducted to discuss the classroom situations. The approaches to teaching such difficult subject matter, as distinguishable in the classroom, were avoidance, denial of the controversy, provocation, representing/considering various perspectives, and eliciting empathy. There was a division between approaches that endeavoured to tone down the controversy versus those aimed at making the controversy more apparent. This difference can be understood as dealing with controversial issues as opposed to teaching controversial issues, which is a fundamental difference in pedagogic approaches.
\end{abstract}

Keywords: controversial issues, teaching strategies, religious education, social studies, classroom observations

\section{Att hantera och undervisa om kontroversiella frågor - Lärares didaktiska förhållningssätt till kontroversiella frågor i religionskunskap och samhällskunskap}

\author{
Sammandrag \\ Vilka didaktiska förhållningssätt använder lärare i klassrummet för att hantera \\ samhälleligt omtvistade och kontroversiella frågor? Den här artikeln fokuserar på hur \\ Mellanösternskonflikterna och relaterade ämnen, teoretiskt inramade som kontro- \\ versiella frågor, behandlas i religionskunskaps- och samhällskunskapsundervisning. \\ Syftet i föreliggande artikel är att analysera lärares didaktiska handlande i undervis- \\ ningssituationer där ämnen förknippade med regionala, kulturella och/eller religiösa \\ konflikter (t.ex. migration, terrorism, radikalisering, främlingsfientlighet, antisemitism
}


och islamofobi) var en del av undervisningen. Vilka didaktiska ansatser kunde urskiljas i klassrummet? Hur reflekterade lärarna över denna undervisning? För att undersöka dessa frågor genomfördes etnografiska klassrumsobservationer av religionskunskapsoch samhällskunskapsundervisning på gymnasiet i Sverige; intervjuer med lärare och elever genomfördes också för att diskutera de observerade klassrumssituationerna. Analysen visar att centrala ansatser var undvikande, förnekande av kontroversen, provokation, representation av olika perspektiv, och strategier som syftade till att skapa empati. Det fanns en skillnad mellan undervisning som sökte tona ner kontroversen jämfört med undervisning som syftade till att synliggöra olika perspektiv och positioner i den kontroversiella frågan. Denna skillnad kan förstås som att hantera kontroversiella frågor jämfört med att undervisa om kontroversiella frågor.

Nyckelord: kontroversiella frågor, undervisningsstrategier, religionskunskap, samhällskunskap, klassrumsobservationer

\section{Introduction}

Interviewer: What is your best advice for teachers?

Student 1: Take in all opinions. Everything that ...

Student 2: Yes, and we must remove the controversial in it. Or, we must remove the term 'controversial views' because if something is controversial, then it means that you can't talk about it from the beginning. (Student interview)

This conversation took place during a focus group interview on experiences of learning about Middle Eastern conflicts pursuant to the so-called Arab Spring uprisings in 2011 (and related topics). These students believed that antagonism, contradictions and ambiguities were silenced instead of highlighted and problematised, and that only 'politically correct opinions' were allowed in the classroom. They raised questions about what limits should be applied to difficult issues that are addressed in the classroom: Is it possible to have a safe and positive learning environment and still express and discuss all kinds of opinions - even if controversial?

In recent years, there have been many events and conflicts across the world upon which polarisation in public debates has increased. Often enough, these have been followed by reactions, with right-wing, populist politicians and parties moving the norms of acceptability with respect to the nature of argumentation and public discourse (Demker, 2014; Moffitt, 2016; Zarkov, 2017). Populism has taken on various forms and expressions in different countries, but the common framework is an emphasis on nationalism and criticism of the 'elite', often combined with tendencies toward anti-immigration and anti-Islam, with representatives of these positions united in their presentation of simplistic solutions of complex problems (Müller, 2019). The emergence of social media and the logic that governs this type of communication tend to reinforce polarisation (Kim, 2017). Today's major societal challenges such as climate change, migration, and 
integration are examples of issues where opinion is divided concerning both problem descriptions and potential solutions.

Issues where it is difficult to draw a clear boundary between facts, knowledge, values and opinions - and where there exist competing interests and perspectives based on alternative views on how they should be solved - are referred to as 'controversial issues' in education and educational research (Ljunggren, Unemar Öst, \& Englund, 2015; Stradling, 1984). They tend to trigger strong emotions and divide opinions in communities and society as well as within classrooms (Kerr \& Huddleston, 2015). Research (see, e.g., Anker \& von der Lippe, 2018; King, 2009; McDermott \& Lanahan, 2012; Niens, O'Connor, \& Smith, 2013; Pollak, Segal, Lefstein, \& Meshulam, 2018) has shown that teachers often find it difficult to handle issues perceived as controversial, with the end result being that they tend to avoid them.

At the same time, the overall aim of schooling is to make the world more comprehensible for students and to provide them with tools that will help them orient themselves in a complex world. Swedish schools also have a formal democracy-promoting mission of preparing young people for active citizenship (Skolverket, 2011a). One way to foster democratic citizens is to let students engage in controversial, politically charged issues (Hess \& McAvoy, 2015; Ljunggren et al., 2015; McAvoy \& Hess, 2013; Pace, 2012; Parker, 2003). One characteristic of controversial issues is contingency, that is, what is controversial in one classroom is not necessarily controversial in another - depending, for example, on the time and place and students' own opinions and experiences (Hess \& McAvoy, 2015; Kello, 2016; Ljunggren, 2015; Ljunggren \& Unemar Öst, 2011; Misco, 2012). In line with social processes such as globalisation, migration, and segregation, heterogeneity and pluralism have increased both in society as a whole and in the classroom setting. This makes it even more difficult for teachers to anticipate which topics will elicit emotional responses in their students or how to handle the lesson if they do. In this article, teaching about the Middle Eastern conflicts and related topics is understood as potentially touching upon, and thereby eliciting, controversial issues in some school contexts. The empirical data of this article consist of (a) classroom observations of religious education (henceforward RE) and social studies lessons in upper secondary schools in Sweden, and (b) interviews with the teachers and students involved in those classes. The investigation is part of the research project Global conflicts with local consequences - learning and arguing about Middle Eastern conflicts in Swedish classrooms. ${ }^{1}$

The aim of the article is to analyse approaches teachers used in situations where controversial issues, here exemplified through topics associated with Middle Eastern conflicts, such as migration, terrorism, radicalisation, right-wing extremism, xenophobia, anti-Semitism and Islamophobia, were part of the

\footnotetext{
${ }^{1}$ The research project was funded by the Swedish Research Council (dnr 2016-03605) and was conducted 20172019 together with professor Göran Larsson and professor Roger Säljö, Gothenburg University.
} 
instructional unit. What pedagogical approaches can be discerned in classroom practices? How do teachers reflect on such teachings?

\section{Definitions of controversial issues}

There are several competing definitions of controversial issues; some focus on political and social aspects (see, e.g., Stradling, 1984; Camicia, 2008), some on behaviour of individuals and/or groups (Bailey, 1975; Advisory Group on Citizenship, 1998; Kerr \& Huddleston, 2015), while others emphasise the epistemological nature of controversial issues (Dearden, 1981; Hand, 2007, 2008). Those who advocate the latter, believe that criteria based solely on the behaviour of individuals and groups run the risk of relativism. Hand (2008) underlines the importance of reason and argues that teachers should "teach as controversial those matters on which contrary views are not contrary to reason, and as settled those matters on which only one view is rationally defensible" (Hand, 2008, p. 228). A criticism leveled against the epistemic criterion concerns that all reasoning is derived from a certain perspective, all social life involves power relations, and controversial issues are dynamic and contingent and must be seen in their historical, contemporary, and ideological contexts (Camicia, 2008). Warnick and Smith (2014) argue that the epistemic criterion of controversial issues in the educational settings does not include fallibilism which they find pivotal - when students learn to argue rationally and develop skills of reasoning, a premise must be that one may be wrong. Cooling believes that the epistemic criterion includes an "over-reliance on the decisiveness of reason and failure to attend to the need for fairness" (Cooling, 2012, p. 169) and he advocates a diversity criterion of controversial issues. The definition of Stradling (1984) also gives attention to the teaching and highlights educational, political and social aspects: "The controversial issues which do tend to pose serious problems for the teacher are those on which society at large (or the local community, or even the school itself) is clearly divided and for which different groups offer conflicting explanations and advocate conflicting solutions based on alternative values." (Stradling, 1984, p. 121). The analysis in this article follows Stradling's (1984) definitions of controversial issues but also includes perspectives focusing on emotions, i.e. behaviour (Kerr \& Huddleston, 2015).

\section{Pedagogical approaches to controversial issues}

Controversial issues often appear in the school environment, not only in relation to specific curricular units and school subjects, but also in the context of cultural expression and events occurring in the community (Huddleston \& Kerr, 2017). In the literature, the contingent nature of controversial issues is stressed, that is, it is difficult to predict what will be perceived as controversial in a particular context (Camicia, 2008). For example, in divided societies or conflict-laden areas, controversies may arise in relation to ethnic, religious, national, and ideological identities of the students, with consequences for classroom discourse (Hanna, 
2017; Kello, 2016; Niens et al., 2013; Pollak et al., 2018; Tamir, 2015). The Swedish educational system is increasingly segregated in terms of socioeconomic and ethnic factors (SOU, 2017); this makes it difficult to anticipate which specific topics of study, or related questions, might be controversial, i.e., cause actual disagreement among the students and give rise to strong emotions in a specific classroom (Nilsson, 2018; Blennow, 2019). However, there are topics that are commonly considered controversial in international research: wars and conflicts, democracy, citizenship, human rights, nuclear weapons, genocide, the Holocaust, family values, homophobia, migration, and various types of racism and discrimination such as Islamophobia, anti-Semitism, anti-Ziganism, gender issues, consumption, and sustainable development (Cowan \& Maitles, 2012; Woolley, 2010).

Differences of opinion, antagonism, and controversial topics are core ingredients of a democratic society. Stradling (1984) problematises dealing with controversial issues in the classroom, arguing that teaching always needs to be contextspecific and responsive to the knowledge and experience of the students. He downplays the notion of a theoretical framework that can be applied across-theboard. Nonetheless, various strands of literature have emerged about approaches and methods for teaching difficult subjects. Some approaches (e.g., Fiehn, 2005; Huddleston \& Kerr, 2017; Kerr \& Huddleston, 2015; Kirschner, 2012; Oxfam, 2018) are more practice-oriented, offering advice to teachers based on 'best practices' methods. Other studies focus on specific methods to be used in teaching controversial issues, for example, discussion (Hand \& Levinson, 2012; Hess, 2009), personal narratives (Barnett, 2011; Levinson, 2008; Rivers, 2015), and role play (Koukounaras-Liagis, 2011; Pilcher, 2017; Shollenberger, 2007). Still other studies (Hess, 2005; Ljunggren \& Unemar Öst, 2010, 2011) have concerned themselves with teacher attitudes and formulation of pedagogical approaches based on the same.

Hess (2005), for instance, argues it is important for teachers to reflect on their own convictions (moral, political, social, etc.) when teaching controversial issues. She distinguishes between four approaches teachers commonly use when discussing and/or instructing in challenging course material: avoidance, denial, privilege, and balance. Teachers who avoid certain questions in the classroom may have a range of motives for so doing. They might be concerned, for example, about potentially triggering in students strong emotions that would be difficult to handle. They may also feel they lack the knowledge and/or training to adequately cope with such a situation, should it occur (cf. Anker \& von der Lippe, 2018; Cotton, 2006; Oulton, Day, Dillon, \& Grace, 2004; Zembylas \& Kambani, 2012). Another reason for avoidance may be that a teacher has a strong opinion on an issue and finds it difficult to stay neutral. Rather than letting such views influence their teaching, they prefer avoiding the issue altogether. Denial means refusing to accept that an issue is controversial and that there may be several possible answers to the question, and Privilege implies that the teacher, in her/his teaching, 
emphasises a specific position as the correct one. Balancing refers to teaching that presents various perspectives and attempts by the teacher to present them as neutrally as possible. Pollak et al. (2018) point to two additional approaches: Sidestepping the controversy, instead emphasising unifying messages that strip away socio-political complexities, and Scholasticising the discussion, that is, shifting the focus from content and toward literacy skills.

Ljunggren and Unemar Öst $(2010,2011)$ analysed the Swedish part of ICCS 2009 (International civic and citizenship education study). The study reveals interesting differences between how teachers and students perceive controversial issues. For example, a higher proportion of teachers than students think that teachers encourage students to express their views and that teaching highlights different and opposing views in a comprehensive manner. The students, though, think that teachers control classroom discussions to a greater extent than teachers believe. When asked how they deal with controversial issues, four main communicative strategies, with different degrees of controversy acceptance, were distinguishable in the teachers' answers. The debate leader has a high degree of acceptance of the controversy, expresses different opinions, and encourages students to express their position(s) and engage in dialogue to support it/them. The norm mediator also articulates a high tolerance for conflict in discussions, but clearly indicates when students express opinions that contradict fundamental democratic values (i.e., refers to the law and to curriculum-based norms). The tutor avoids discussion of controversial issues in the classroom, but addresses controversial issues individually with the student. The rejector prevents dialogue both in the classroom and individually and marks his/her distance from difficult topics. Of these, the norm mediator was by far most common in teachers' articulations as to how they handle controversial issues, followed by the debate leader (Ljunggren \& Unemar Öst, 2011).

\section{Method}

\section{The empirical material}

The empirical material of this article is part of a research project funded by the Swedish Research Council that aims to analyse how the conflicts in the Middle East are dealt with in Swedish schools. The study took an ethnographic approach, i.e., making participant observations of RE and social studies classes in upper secondary schools and, as well, in an adult education class. In connection with these observations, individual interviews were conducted with the teachers, while student opinions were elicited through a series of focus groups. 


\begin{tabular}{l|l} 
Empirical material & Number \\
\hline Schools & $\mathbf{7}$ \\
\hline Observed lessons & $\mathbf{3 8}$ \\
& 12 Social Studies lessons + 2 days EU role play + 1 theatre play. \\
& 24 Religious Education lessons + 2 theatre plays. \\
\hline Individual interviews with teachers & $\mathbf{1 2}$ \\
\hline $\begin{array}{l}\text { Focus-group interviews with } \\
\text { students }\end{array}$ & $\mathbf{1 5}$ \\
\hline
\end{tabular}

Seven schools were examined in total. Two of the schools are centrally located in one of the largest cities in Sweden, two in medium-sized cities, two in smaller communities/rural areas, and one in a suburb of a relatively large city. The selection of schools was intended to derive a varied and diverse sample of classroom contexts with students with different socioeconomic and cultural backgrounds.

In Sweden, RE and social studies are mandatory subjects in both compulsory school and upper secondary school. RE is a non-confessional and non-denominational school subject, and all students are taught together regardless of religious or non-religious affiliation. Controversial issues are not an explicit content matter in either of the subjects but both subjects involve issues that with the above definitions could be perceived as controversial. According to the syllabus, social studies aims to "give students the opportunity to develop knowledge of issues relating to power, democracy, gender equality and human rights" (Skolverket, 2011b). Besides knowledge of religions, worldviews and ethics, teaching in RE should "take as its starting point a view of society characterised by openness regarding lifestyle, outlooks on life, differences between people, and also give students the opportunity to develop a preparedness for understanding and living in a society characterised by diversity" (Skolverket, 2011c).

When inviting each school to participate in the study, the researcher asked the teachers of the classes to be observed if it would be possible to make participant classroom observations during RE and social studies lessons that somehow touched on the conflicts in the Middle East and related themes. The content areas that thus became relevant were based on the teachers' interpretation of our request and experiences of the content they taught; they concerned religion and conflicts, migration, terrorism, human rights, and the monotheistic religions.

\section{Definitions}

One challenge during the analysis was not only to operationalise controversial issues in order to identify when such issues were at stake, but also to discern approaches in the classroom practice adopted by the teachers to controversial issues. The analysis was based on the following definition of controversial issue which combines political (Stradling, 1984) and behavioural (Bailey, 1975; Huddleston \& Kerr, 2015) criteria of controversial issues: content and themes that accommodate both facts and values and where it was difficult to draw a sharp distinction between facts and opinions and issues where teachers and/or students 
had strong opinions or feelings. In this article, pedagogical approaches are understood as how teachers acted and/or verbally positioned themselves when these types of questions came up in the classroom. In the interviews, questions were posed about situations in the classroom when controversial issues had been addressed. The interviewees were able to describe (as best they could) their own motives and also reflect on their own and others' actions and verbal positions.

\section{Analysis}

During fieldwork, continuous field notes were made, and classroom observations and interviews were audiorecorded and transcribed verbatim. The analysis had an inductive approach, with the aim of studying how controversial issues appeared in the classroom practice in the interplay between content, students and teachers (cf. the didactic triangle: Hopmann, 1997) with a particular focus on the teachers' actions and representations of content. Through qualitative content analysis, a coding frame, based on the above definitions of controversial issues, was generated. The transcribed interviews and classroom observations were categorised and coded accordingly, in order to distinguish patterns and variations in pedagogical approaches of controversial issues (Bryman, 2012; Schreier, 2012). For this article, the field notes (with reflections on interactions in the classrooms) were used to contextualise the observations. Special attention, for example, was given to verbal expressions as well as more subtle indicators of responses and/or feelings (e.g., knowing looks between students, sighs, averting one's gaze, etc.) in order to explicate relationships in the classroom (both interactions among students and those between teachers and students). In order to make interpretation of the empirical material as apparent as possible, quite extensive direct quotes are used in presenting the results below.

\section{Ethics}

The study was reviewed by the Regional Ethical Review Board in Gothenburg. The Board decided that Swedish legislation on ethical review did not apply in this case, but gave an advisory statement. This advice was followed, as were the general principles of research ethics, as formulated by the Swedish Research Council (Vetenskapsrådet, 2017). In displaying the results, to protect the integrity of the participants, 'teacher' is used to refer to all the teachers; likewise, 'student' refers to all the students. If there were several students in the same quoted exchange, the students are referred to as 'Student 1', 'Student 2', etc.

\section{Results}

As mentioned, the aim of the research reported in this article is to identify pedagogical approaches and positions among teachers on controversial cultural, political, social and religious issues (in this case, as arose in the context of 
teaching about the Middle Eastern conflicts and related themes). This content was understood as potentially controversial in many classrooms. The analysis indicated that whether or not an issue was considered controversial was not so much related to the epistemological nature of the question, but rather to the students' (and teachers') emotional reactions and their positions on the issue within a given classroom context. The contents thereby revealed as controversial were: the Israeli-Palestinian and Syrian conflicts, xenophobia and anti-immigration attitudes, right-wing extremism, Islam and terrorism, human rights, and same-sex marriage. Because of the limited format of a single article, the results section focuses strictly on the pedagogical approaches applied by the teachers in trying to address/handle these issues (as opposed to the various and contrasting opinions regarding the issues per se). The results are presented based on the two main categories of teachers' approaches of controversial issues: dealing with issues that become controversial in the specific classroom practice, and teaching controversial issues where the teacher explicitly addressed the controversy in the teaching.

\section{Dealing with controversial issues Avoidance}

It is always difficult to determine what is not being said, i.e., to evaluate whether a question or issue is deliberately being avoided. Nevertheless, during the class observations, it became clear that several teachers in this study wilfully avoided, or tried to avoid, certain topics (e.g., overlooking certain comments from students, interrupting, and/or preventing some students from speaking).

However, all teachers in this study maintained the desire to raise all kinds of issues - including those expected to be controversial - considering it crucial in education to address such questions/topics/subject matter. One teacher expressed this principled attitude as follows: "If you sidestep these questions, you actually fail the students as well." However, teachers and students alike confirmed that certain topics were avoided in the classroom; further, the teachers reported occasionally trying to steer the discussion away from emotionally charged content. During the interviews, teachers and students both alluded to various reasons for avoiding certain issues. The teachers, for example, raised a concern about engendering conflicts in the classroom:

Teacher: You are so afraid that it will explode. You are afraid of the explosion. They [the teachers] are afraid of conflicts. And, yes, this reinforces prejudice. You do this not to consolidate prejudice, but prejudices are confirmed if you never talk about them and try to find understanding. (Teacher interview, school 5)

Several teachers emphasised concerns about losing control in the classroom as the primary reason for avoiding certain questions. Losing control of that environment might be frightening enough but, if a discussion is charged, this also can mean that some students may feel violated - or even threatened. In this regard, the 
teachers stressed their sense of responsibility to ensure that everyone felt safe in their class.

Other reasons for avoiding questions concerned issues of complexity and knowledge (or lack thereof):

Teacher: But the [Syrian conflict] is incredibly complex and changes all the time. It might cause you to back off, because there is nothing ... rarely is there something black and white, but it is an incredible number of grey zones and ... For example, the classic, if you fight ISIS [The Islamic State, also known as Daesh] and then maybe you indirectly support Assad [Bashar al-Assad, the current president in Syria]. Or that you support a guerrilla group that really has terrible opinions about women or other religious groups. So these are very complex issues. (Teacher interview, school 2)

Controversial issues are multifaceted and complex in nature; for this reason, teachers' content knowledge is central to their ability to teach high-quality classes. Another concern mentioned by the teachers was lack of time: because such issues are complex, they require considerable classroom time to fully discuss them and render the broad range of perspectives visible. Both RE and social studies are subjects that have extensive syllabi in relation to the amount of time allotted to cover the content stated in the subject syllabi.

\section{Denial of the controversy}

The definition of controversial issues assumes difficulties with ascribing a sharp boundary between facts and opinions - additionally, such issues tend to stir up strong emotions. One approach used by the teachers, with this in mind, was to raise an issue as unambiguous - and therefore non-controversial. The following example of teaching about human rights illustrates this approach:

Teacher: Human rights. There is surely a word, all of you ... Hush ... that you have all heard about. And there can be both positive and negative feelings about the word, what it means. And now we already have one here that grins, and one who laughs. So, I understand that there are many thoughts on this subject. I will focus on learning what it means, and we will discuss a bit what you think and feel. (Classroom observation, school 4)

As shown in the above quote, it was the teacher's wish that students take note of facts pertaining to a topic and then discuss them. In this class, though, there were several students who were asylum seekers; there also were students who had been denied asylum and were now living as undocumented and homeless persons while still trying to complete their schooling. Some had been rejected on the grounds that they could not prove their identity because they lacked passports or proper documents. During the lesson, all sections of the UN Declaration on Human Rights were read aloud, including $\S 6$ "Everyone has the right to recognition everywhere as a person before the law" and $\S 14$ "Everyone has the right to seek and to enjoy in other countries asylum from persecution". When the teacher read these paragraphs, some students made faces and gave each other knowing looks, but 
did not say anything aloud. The paragraph the teacher especially commented on was $§ 16$, concerning the right to choose a marriage partner. Gender equality is stressed as an essential value in Sweden; the right to marry also applies, legally, to people of the same sex. Focusing on this paragraph can be interpreted as the teacher manoeuvring between different controversial issues. The ensuing interview revealed that the teacher assumed that all three issues - homosexuality, right to asylum, and recognition as a person - could be controversial in this classroom, and chose to handle each in different ways. Homosexuality, for instance, was not treated as controversial by the teacher; she stated that, in Sweden, homosexuality is a non-controversial issue (thus presenting this attitude as the only possible one). She did this, despite knowing that some of the students entertained quite conservative views on gender and same-sex marriage. When it came to asylum and an individual's right to life, freedom, and security, it became obvious through the students' body language and faces that they questioned the teaching based on their own personal experiences. Later, in the interview, the teacher reflected on this situation:

Teacher: I had thought about this before and there are several ways of approaching this, but my approach was that I inform. I acknowledge the students, when I saw that they made faces and sighed, like this, I made clear that I saw this. You must also be very neutral. Then, when I meet some student in the corridor, we can stand there and complain [about circumstances], and we can say 'what a shame it is'. But just in context of the lessons, I must keep it neutral ... both to protect myself and to protect the students, and not bury myself in things that I cannot change anyway. But I see my role as informing, educating, and listening to them. But of course, it was ... I had a little stomach ache before, so I had. Because I knew exactly how some [students] would react. But I thought there was very little ... [there were] fewer reactions than I had expected. It was very low key. (Teacher interview, school 4)

In the observed classes, the Declaration of Human Rights was presented as unambiguous, i.e., as a document that could not be criticised - the assumption being that all human beings are entitled to these rights. Whether everyone actually enjoys these rights or not - and the reasons this might not be the case - were not discussed or problematised. As there were students involved in an ongoing asylum process (in which, according to what some students said in the interviews, the Swedish Migration Agency mistrusted their stories), this issue became highly controversial and, obviously, aroused much emotion, both within some of the students and in the teacher. The affected students did not say much in the classroom but later, in their interviews, recounted how they felt during the discussion. Most said they understood it was the teacher's job to talk about human rights, but that, in their view, they were just nice words on paper (with little or no meaning - at least not for all human beings). Omitting different perspectives and interpretations of these rights thus became a way of managing potential controversy in the classroom. 
A similar approach - but adopted for another reason - was when teachers put the lid on discussions by referring to school law and curricula:

Teacher: The students ask if it is ok to be a Nazi and if you [are allowed to] think whatever [you want].

Interviewer: They test you a little there?

Teacher: They're testing. Yes, they do.

Interviewer: Then what do you answer?

Teacher: I answer that we don't stand for those views. I refer to the curriculum straight away because we don't think so, we shouldn't think so.

Interviewer: What do they answer then?

Teacher: Yeah, it's usually a pretty big silence then. So, it's not anyone ... It depends, if it is pedagogical or not, but I still think we have an obligation to say what we stand for. Otherwise, we have just formulated something on paper ... But it actually means this. The curriculum states that you should have solidarity with the vulnerable and so on. (Teacher interview, school 2)

Both in this quote and in the above example related to same-sex marriage, the teachers give privilege - with reference to Swedish law and the curriculum - to one specific position related to Nazism and homosexuality (cf. Hess, 2005). The teachers see this as a professional obligation not to discuss such issues as controversial - even though there may be divergent views on the subject.

\section{Teaching controversial issues Provocation}

Some teachers recounted that, in their instruction, they wanted to challenge the students' perceptions by provoking them. This could be done by raising perspectives and opinions that, in their expectation, might obtain a strong reaction in - or at least in some of - the students. In the following quote, this approach is described by a teacher who introduced the theme of terrorism in a class. He had written 'terrorism' on the whiteboard and asked the students what they thought when they saw that word:

Teacher: To provoke them a little bit, and at least then see ... hope they would see their own, if you say, prejudice or something about it. Thus, they - quote, 'Swedish students' - were so friendly and politically correct, they did not dare to say 'Muslim' out of respect for others with a Muslim background sitting in the classroom - which is quite okay. But, at the same time - again, with quotation marks - I know that many of them thought 'Muslims, Islam'. Because that's the picture of it [terrorism]. So, this was my purpose, to provoke this. (Teacher interview, school 3)

Several of the students with Muslim background brought up this situation in the interviews, expressing that they indeed had felt being singled out as that religious /ethnic group (Muslims) - and thereby associated with terrorism. However, they also indicated they did not express this in class. It likely was not the intention of the teacher to single them out, but this was the way it was perceived by the 
students. In other words, it is a delicate balancing act to use provocation as an approach when teaching about controversial issues.

\section{Representing different perspectives}

When it came to value conflicts, different approaches were observable. Some teachers emphasised the importance of communicating democratic values and respect for all humans' equal value, while others stressed the importance of highlighting different perspectives in education. Those who emphasised the latter often referred to the wording in the syllabi of RE and social studies, which state that in order to achieve higher grades, i.e. A and B, the students needed to show an awareness of various perspectives and be able to discuss or reason such in an 'elaborate and nuanced' way. One of the teachers illustrated this by holding up her laptop and asking two students to describe the laptop from different sides:

Teacher: It is only when I see this from different angles that I will see the whole laptop. We may even need to lift it up. Say now the table is transparent and some bastard sits under it. Then you'd see that it has these flaps underneath. I can't see this from here [pointing to the backside of the laptop]. You can't see how it looks from below. But when you listen to different opinions about things, then we get a greater understanding. Are you with me?

Student: Mm.

Teacher: So being nuanced and understanding how to reach the higher grades, it's also about listening to others, hearing others' views on the same thing. And that does not mean they are more correct or that I am more right. It is all about adding pieces to the puzzle. This is how we work in RE. (Classroom observation, school 5)

A few weeks later she returned to this analogy in class, using the formulation of the grading system as an argument - in discussions - to raise more perspectives on the same question:

Teacher: So, what I want with the lessons is that you learn about the background of different things and understand their context - instead of starting with, 'how can they think so and they make mistakes and they ...' There are many different views of the same coin. Do you remember the lesson [presented in the above quote] we had when we looked at some laptop and said, 'we look at it, we can describe it differently depending on which side we see it from'?

Student: Mm.

Teacher: And so it is with this conflict. I'm not a Jew, I'm not a Muslim. But I still can imagine what it would be like if someone came to say that 'you have to move out, I'll stay here'. Then I would be mad too. But I also can imagine what it would be like not to have a country, that all my relatives first had been thrown into a ghetto and then we were taken to a camp [...] So, what we must do as human beings here today is to try to understand.

Student: And don't judge straight away.

Teacher: And don't judge right away. Do you understand?

Student: Yes.

Teacher: And then we can think of a lot of things, because we start from ourselves. But sometimes we must take a helicopter perspective, go back into history and understand 
why Jerusalem is important, why is this country so important? [...] And we can continue to be ones who only see the differences. But we can also try to see the similarities and become more human by trying to be empathetic and not judge directly without thinking 'Yeah, how could it have gotten this way?' (Classroom observation, school 5)

This teacher works in a context where most students have Muslim cultural backgrounds; thus, sometimes discussions arise about who has the correct interpretation of Islam. This sometimes leads to animated discussions and the teacher had an explicit pedagogical approach to handle this:

Teacher: I think it's great they give each other new perspectives, but there mustn't be personal attacks. And that's why I always come back to: 'Stop! Talk! No debate-boxing! 'Nuanced', what does that mean?' Then I can do role-playing with myself again, if needed, until they [the students] understand that 'you will not reach the A-criterion if you go on and fuss about 'this is being the only truth and you are wrong' - because then you are not using nuanced reasoning'. So, I use the grade criteria both as a threat and a temptation. But somewhere it is ... the overall is not the grades. It's just means, a tool, a recipe. The overall aim, after all, is that they develop as human beings and listen to other. (Teacher interview, school 5)

Questions related to religion were generally perceived as more 'sensitive'. Several of the teachers described them as more difficult to handle; altogether, there was greater uncertainty when it came to religious positions. The teacher in the quote above is an exception, as she - on the one hand - constantly emphasised the importance of discerning and illustrating various positions but, at the same time had a consistent approach with respect to how the conversation should be conducted in the classroom. This teacher had extensive experience working in a multireligious environment and had developed an intercultural competence when it comes to making interpretations within the same religious tradition. A prerequisite for this was a solid knowledge of different paradigms of interpretation. Several teachers expressed uncertainty and a lack of knowledge, which made them occasionally avoid controversial issues related to religion. In this way, issues related to right-wing extremism and LGBTQ identity became less controversial than those related to religion because the teachers believed they had support in the Education Act (SFS, 2010:800, Chap. $1 \S 4$ ) - and, further, a curriculum enabling taking a stand concerning democratic values and equality.

There was a variation among the teachers whether they organised their teaching based on students' opinions and reflections on different issues or if the teaching primarily was based on a given factual content. Some teachers suggested that discussion of controversial issues without an explicit fact base, was absolutely devastating:

Teacher: 'This is what we're going to talk about today. What do you say? The death penalty, is it right or wrong?' Yes, what the hell will that lesson lead to? It will be crap. How should we be able to discuss something we do not know anything about? (Teacher interview, school 5) 
Other teachers thought that all students were entitled to their opinion and took the views represented in the classroom as a starting point for discussions.

\section{Creating empathy}

Two of the teachers let their students watch a theatre play that, in itself, raised issues that were controversial and which they discussed in the classes they taught (Flensner, Larsson, \& Säljö, 2019). One class in RE got to see a play about a young man's radicalisation process. In this class, there was a student who had expressed sympathy for Islamist interpretations of Islam. Another class in social studies got to see a play concerning migration and identity, based on a story portraying the escape of a mother and daughter from war and poverty. Some students in the class had strong migration-critical views with xenophobic undertones, while there were also students in the class who recently had come to Sweden as refugees. The topics of the plays were thus controversial in their respective school contexts. These teachers' approach was to highlight personal narratives in the form of theatre as a perspective on the controversial issue, thereby contributing to increased understanding and empathy for their situations:

Teacher: I was thinking, 'will they understand?' And then I [wonder], what do we mean by understanding? No, they won't understand. But I don't understand the refugee crisis either. So, what are they to understand? Well, that is, they must get some kind of idea that these are humans on the run, and that is what I want to achieve. (Teacher interview, school 2)

This teacher, who worked with migration, argued that these types of questions must be allowed to stay complex. But his overall goal was for students to understand that migration is always about people, that it is human beings who migrate. The class also worked on this theme in other ways. However, by emphasising humanity and empathy, he argued, the students' understanding would become more nuanced.

\section{Discussion}

The aim of this article has been to analyse approaches teachers used in the classroom in situations where potentially controversial issues were part of the teaching, and to document reflections on such teaching. The teacher approaches distinguishable in the classroom were that of dealing with controversial issues through approaches of avoidance or denial of the controversy, and teaching controversial issues through approaches of provocation, representing different perspectives, or creating empathy. The teachers oscillated among various approaches and chose different approaches at various times.

The teachers' pedagogical approaches were related to what was perceived as controversial in the specific classroom. This study does not involve identical 
teaching, nor teaching in the same subject concerning the same content. For this reason, it is not possible to make a comparison across the schools or classrooms and state whether a certain issue was controversial at one school but not at another. However, based on the observations in this study, it seems clear that whether an issue was perceived as controversial or not was primarily not related to the epistemological nature of the issue (cf. Hand, 2008), but rather to if the issue aroused strong feelings among the students (and teachers). In this sense, controversial issues are contextually linked to a specific situation where students' experiences and perceptions influence how different concerns are understood and discussed (cf. Ljunggren \& Unemar Öst, 2011; Stradling, 1984). Although controversial issues contain both facts and opinions, they also have the potential to contribute - not only to an increased knowledge of factual content and different positions in the field - but also to knowing how to deal with antagonism and disagreements, which is a fundamental competence in a democratic but increasingly polarised society.

There is a dividing line between approaches that endeavour to tone down the controversies and approaches, as opposed to those endeavouring to make the controversy visible. Approaches of avoidance and denial of the controversy are examples of the former, while approaches of provocation, representing different perspectives, and creating empathy had the stated purpose of challenging students' perceptions and making different perspectives visible. This difference can be understood as dealing with controversial issues as opposed to teaching controversial issues - a fundamental difference in approaches, which is a distinction also made by Ljunggren and Unemar Öst (2011).

This difference across approaches relates not only to how teachers managed to manoeuvre through a range of disparate views and make various positions visible, but also to how they selected approaches appropriate to handling conflicts of opinion and/or various disagreements. In the interviews with the teachers, it became clear that the choice of pedagogical approaches in specific situations when an issue in the classroom practice threatened to trigger emotions, largely was determined by their views on the teacher role and how they related to conflicts. Some teachers were more uneasy in conflicted circumstances and experienced situations with strong antagonism as unpleasant. These teachers, by and large, tried to tone down the controversy or avoid it altogether. Others did not have much trouble with such attitudes, but rather took control of the classroom through using an explicit pedagogical approach of teaching controversial issues and not merely dealing with them. Compared to the communicative strategies of Ljunggren and Unemar Öst (2011), approaches of avoidance or denial of the controversy, with their typologies, can be described as tutor and rejector, while approaches of representing different perspectives and creating empathy more has the character of debate leader or norm mediator. The teachers in this study, in principle, wanted an open conversation climate. There is, however, a fundamental difference between teachers' reasoned arguments for what they do, and 
approaches applied in classroom practice. When it came to certain questions, they argued that they had a duty to intervene and mediate, for example by focusing on democratic values, LGBTQ rights, and gender equality. In the specific cases, norm mediation meant that the controversy and different positions were not made explicit to the students and, with reference to curricula, certain values that 'we should have' were privileged (cf. Hess, 2005).

The teachers who worked on representing a range of different perspectives were very well informed; they constantly emphasised that teaching was about positions in the subject matter based on available knowledge, as opposed to a presentation of the students' own perceptions and opinions. In line with Hess (2009) and Hand and Levinson (2012), they also had conscious and explicit strategies for how to discuss issues in the classroom; in so doing, they managed to maintain this way of discussing such issues.

The classroom is a mirror of society, but it is also a space where students learn to socialise, converse, and familiarise themselves with how other people think even if those persons have different views than themselves. As compared to the other parts of society, the interaction in school is compulsory; most often, it is not possible to select those with whom one interacts (i.e., other students and teachers). However, if teachers completely avoid presenting difficult questions, the students themselves are left with these questions - though lacking preparation for dealing with controversial topics outside the school milieu. Several of the students recounted that they talk more often about some of the issues and conflicts addressed in this article in the school hallways than in the classroom(s). That said, though, they tend to discuss issues with friends who mostly share their views and are seldom challenged by alternative worldviews or explanations.

The school has a mission to promote democracy, and one of democracy's cornerstones is to learn to agree to disagree (cf. Iversen, 2019; Flensner \& von der Lippe, 2019). To always strive for total consensus is problematic in a democratic society. At the same time, there might be certain values and rules that we must agree upon for a society to function. There is a great deal of research (e.g., Anker \& von der Lippe, 2018; Cotton, 2006; Oulton et al., 2004) showing that teachers tend to avoid topics they perceive as controversial. If teachers put the lid on political discussions and avoid raising controversial views that, for example, challenge democratic values, some issues could live, prosper and grow beneath the radar and will not be challenged, problematised or even stopped (if they are violating the legal system). At the same time, after observing teaching at all these schools, I also would like to emphasise that, in certain situations, it can be the most professional to just avoid certain issues. It should be emphasised that the teacher profession is a practical profession, wherein teachers' knowledge and professional considerations are implemented in a specific context. Teaching is thus a balancing act between different goals. There is research showing that sometimes teaching reinforces the prejudices it aims to counter, as shown by Mattsson (2018) in his study of young neo-Nazis in Swedish schools. However, 
although teachers see it as their duty to promote specific values, it should be possible to create a classroom of disagreement that can be a space where the world becomes a bit more understandable (instead of the opposite).

\section{About the author}

Karin K. Flensner has a PhD in religious studies with a focus on didaktik and educational sciences. She works as senior lecturer in educational science in teacher education. Her research addresses issues of integration, inclusion, religion, democracy and citizenship in the pluralistic society related to educational contexts.

Institutional affiliation: Department of Social and Behavioural Studies, University West, Gustava Melins gata 2, S- 46132 Trollhättan, Sweden. E-mail: karin.flensner@hv.se

\section{References}

Advisory Group on Citizenship (1998). Education for citizenship and the teaching of democracy in schools. "The Crick report”. London: Qualifications and Curriculum Authority. https://dera.ioe.ac.uk/4385/1/crickreport1998.pdf

Anker, T., \& von der Lippe, M. (2018). Controversial issues in Religious Education: How teachers deal with terrorism in their teaching. In F. Schweitzer \& R. Boschki (Eds.), Researching Religious Education (pp. 131-143). Munster: Waxmann.

Bailey, C. (1975). Neutrality and rationality in teaching. In D. Bridges \& P. Scrimshaw (Eds.), Values and authority in schools [pp. 122-144]. London: Hodder \& Stoughton.

Barnett, P. E. (2011). Discussions across difference: Addressing the affective dimensions of teaching diverse students about diversity. Teaching in Higher Education, 16(6), 669-679.

Blennow, K. (2019). The emotional community of social science teaching. Dissertation, Lunds universitet. Media-Tryck.

Bryman, A. (2012). Social research methods. Oxford: Oxford University Press.

Camicia, S. P. (2008) Deciding what is a controversial issue: A case study of social studies curriculum controversy. Theory \& Research in Social Education, 36(4), 298-316. https://doi.org/10.1080/00933104.2008.10473378

Cooling, T. (2012). What is a controversial issue? Implications for the treatment of religious beliefs in education. Journal of Beliefs \& Values, 33(2), 169-181. https://doi.org/10.1080/13617672.2012.694060

Cotton, D. R. E. (2006). Teaching controversial environmental issues: neutrality and balance in the reality of the classroom. Educational Research, 48(2), 223-241. https://doi.org/10.1080/00131880600732306

Cowan, P., \& Maitles, H. (2012). Teaching controversial issues in the classroom: key issues and debates. London: Continuum.

Dearden, R. F. (1981). Controversial Issues and the Curriculum. Journal of Curriculum Studies, 13(1), 37-44. https://doi.org/10.1080/0022027810130105

Demker, M. (2014). Sverige åt svenskarna: motstånd och mobilisering mot invandring och invandrare i Sverige [Sweden to the Swedes: resistance and mobilization against immigration and immigrants in Sweden]. Stockholm: Atlas. 
Fiehn, J. (2005). Agree to Disagree: Citizenship and Controversial Issues. Learning and Skills Development Agency (LSDA), Department for Education and Skills (DfES) and the European Social Fund. http://www.activecitizensfe.org.uk/uploads/2/2/9/1/22910514/agree_to_disagree.pdf

Flensner, K. K., Larsson, G., \& Säljö, R. (2019). Jihadists and refugees at the theatre: Global conflicts in classroom practices in Sweden. Education Sciences, 9(2), 80, 1-17. https://doi.org/10.3390/educsci9020080

Flensner, K. K., \& von der Lippe, M. (2019). Being safe from what and safe for whom? A critical discussion of the conceptual metaphor of 'safe space'. Intercultural Education, 30(3), 275-288. https://doi.org/10.1080/14675986.2019.1540102

Hand, M. (2008). What should we teach as controversial? Defense of the epistemic criterion. Educational Theory, 58(2), 213-228.

Hand, M. (2007). Should We Teach Homosexuality as a Controversial Issue? Theory and Research in Education, 5(1), 69-86.

Hand, M., \& Levinson, R. (2012). Discussing controversial issues in the classroom. Educational Philosophy and Theory, 44(6), 614-629. http://doi.org/10.1111/j.1469$\underline{5812.2010 .00732 . x}$

Hanna, H. (2017). Dealing with difference in the divided educational context: Balancing freedom of expression and non-discrimination in Northern Ireland and Israel. Compare: A Journal of Comparative and International Education, 47(1), 17-31.

Hess, D. E. (2005). How do teachers' political views influence teaching about controversial issues? Social Education, 69(1), 47-48.

Hess, D. E. (2009). Controversy in the classroom: the democratic power of discussion. New York: Routledge.

Hess, D. E., \& McAvoy, P. (2015). The political classroom: evidence and ethics in democratic education. New York: Routledge.

Hopmann, S. (1997). Wolfgang Klafki och den tyska didaktiken [Wolfgang Klafki and the German didaktik]. In M. Uljens (Ed.), Didaktik - teori, reflektion och praktik [Didaktik theory, reflection and practice] (pp. 198-214). Lund: Studentlitteratur.

Huddleston, T., \& Kerr, D. (Eds) (2015). Living with Controversy. Teaching Controversial Issues through Education for Democratic Citizenship and Human Rights (EDC/HRE). Training Pack for Teachers. Strasbourg: Council of Europe.

Huddleston, T., \& Kerr, D. (Eds.) (2017). Managing controversy. Developing a strategy for handling controversy and teaching controversial issues in schools. A self-reflection tool for school leaders and senior managers. Council of Europe.

Iversen, L. L. (2019). From safe spaces to communities of disagreement. British Journal of Religious Education, 41(3), 315-326. https://doi.org/10.1080/01416200.2018.1445617

Kello, K. (2016). Sensitive and controversial issues in the classroom: Teaching history in a divided society. Teachers and Teaching: Theory and Practice, 22(1), 35-53.

Kerr, D., \& Huddleston, T. (Eds.) (2015). Living with controversy. Teaching controversial issues through education for democratic citizenship and human rights (EDC/HRE). Training pack for teachers. Council of Europe.

Kim, Y. (2017). Knowledge versus beliefs: How knowledge and beliefs mediate the influence of likeminded media use on political polarization and participation. Journal of Broadcasting \& Electronic Media, 61(4), 658-681. https://doi.org/10.1080/08838151.2017.1375497

King, J. T. (2009). Teaching and learning about controversial issues: Lessons from Northern Ireland. Theory and Research in Social Education, 37(2), 215-246. 
Kirschner, S. A. (2012). Teaching the Middle East: Pedagogy in a charged classroom. PS: Political Science \& Politics, 45(4), 753-758. https://doi.org/10.1017/S1049096512000753

Koukounaras-Liagis, M. (2011). Can an educational intervention, specifically Theatre in Education, influence students' perceptions of and attitudes to cultural and religious diversity? A socio-educational research. British Journal of Religious Education, 33(1), 75-89. https://doi.org/10.1080/01416200.2011.523526

Levinson, R. (2008). Promoting the role of the personal narrative in teaching controversial socio-scientific issues. Science \& Education, 17(8), 855-871.

Ljunggren, C., \& Unemar Öst, I. (2010). Skolors och lärares kontrovershantering [Schools and teachers handeling of controversial issues]. In Skolverket (Ed.), Skolor som politiska arenor. Medborgarkompetens och kontrovershantering [Schools as political arenas. Citizenship education and maneuvering controversies]. Analysrapport 3452010. Stockholm: Skolverket.

Ljunggren, C., \& Unemar Öst, I. (2011). Teachers’ dealings with controversial issues - a typology from the 2009 IEA/ICCS study. Politics, Culture and Socialisation, 2(3), 273294.

Ljunggren, C., Unemar Öst, I., \& Englund, T. (2015). Kontroversiella frågor: om kunskap och politik i samhällsundervisningen [Controversial issues: about knowledge and politics in civics education]. Malmö: Gleerups Utbildning.

Ljunggren, C. (2015). Det offentliga rummet [The public room]. In C. Ljunggren, I. Unemar Öst, \& T. Englund (Eds.), Kontroversiella frågor. Om kunskap och politik i samhällsundervisningen [Controversial issues: about knowledge and politics in civics education]. Malmö: Gleerups.

Mattsson, C. (2018). Extremisten i klassrummet: perspektiv på skolans förväntade ansvar att förhindra framtida terrorism [The extremist in the classroom. Perspectives on the expected responsibility of the school to prevent future terrorism]. Göteborg: Acta universitatis Gothoburgensis.

McAvoy, P., \& Hess, D. (2013). Classroom deliberation in an era of political polarization. Curriculum Inquiry, 43(1), 14-47.

McDermott, P., \& Lanahan, B. K. (2012). Democracy and social justice in Sarajevo’s schools. The Qualitative Report, 17(11), 1-27.

Misco, T. (2012). The importance of context for teaching controversial issues in international settings. International Education, 42(1), 69-84.

Moffitt, B. (2016). The global rise of populism: Performance, political style, and representation. Stanford, California: Stanford University Press.

Müller, J.-W. (2019). Vad är populism?: en essä [What is populism? An essay]. Andra upplagan. Riga: Bokförlaget Daidalos.

Niens, U., O’Connor, U., \& Smith, A. (2013). Citizenship education in divided societies: teachers' perspectives in Northern Ireland. Citizenship Studies, 17(1), 128-141. https://doi.org/10.1080/13621025.2012.716214

Nilsson, S. (2018). Det oförutsägbara klassrummet - utmaningar och möjligheter [The unpredictable classroom - challenges and opportunities]. In O. Franck \& P. Thalén (Eds.), Interkulturell religionsdidaktik - utmaningar och möjligheter [Intercultural pedagogy of Religious Education - challenges and opportunities] (pp. 109-129). Lund: Studentlitteratur.

Oulton, C., Day, V., Dillon, J., \& Grace, M. (2004). Controversial issues - teachers' attitudes and practices in the context of citizenship education. Oxford Review of Education, 30(4), 489-507. https://doi.org/10.1080/0305498042000303973 
Oxfam (2018). Teaching controversial issues. A guide for teachers. https://www.oxfam.org.uk/education/resources/teaching-controversial-issues

Pace, J. (2012). The charged classroom: Predicaments and possibilities for democratic teaching. New York: Routledge.

Parker, W. C. (2003). Teaching democracy: unity and diversity in public life. New York: Teacher's College Press.

Pilcher, K. (2017). Politicising the personal: the resistant potential of creative pedagogies in teaching and learning sensitive issues. Teaching in Higher Education, 22(8), 975-990.

Pollak, I., Segal, A., Lefstein, A., \& Meshulam, A. (2018). Teaching controversial issues in a fragile democracy: Defusing deliberation in Israeli primary classrooms. Journal of Curriculum Studies, 50(3), 387-409.

Rivers, B. (2015). Narrative power: Playback theatre as cultural resistance in occupied Palestine. Research in Drama Education. The Journal of Applied Theatre and Performance, 20(2), 155-172.

Schreier, M. (2012). Qualitative content analysis in practice. Los Angeles: SAGE.

SFS (2010). Skollagen [The Education Act]. Stockholm: SFS 2010:800.

Shollenberger, K. (2007). Student theater confronts controversy to create safer middle school communities. Middle School Journal, 35(5), 32-40.

Skolverket (2011a). Läroplan, examensmål och gymnasiegemensamma ämnen för gymnasieskola 2011, Lgy 11 [Curriculum for the upper secondary school]. Stockholm: Skolverket [The Swedish National Agency for Education].

Skolverket (2011b). Ämnesplan Samhällskunskap för gymnasieskolan [Syllabus Social Studies for upper seccondary school]. Stockholm: Skolverket [The Swedish National Agency for Education].

Skolverket (2011c). Ämnesplan Religionskunskap för gymnasieskolan [Syllabus Religious Education for upper seccondary school]. Stockholm: Skolverket [The Swedish National Agency for Education].

SOU (2017:35). Samling för skolan - Nationell strategi för kunskap och likvärdighet: slutbetänkande [Together for school: national strategy for knowledge and equivalence: final report]. (978-91-38-24601-6). Stockholm: Wolters Kluwer. http://www.regeringen.se/rattsdokument/statens-offentliga-utredningar/2017/04/sou$\underline{201735}$

Stradling, R. (1984). The teaching of controversial issues: an evaluation. Educational Review, 36(2), 121-129. https://doi.org/10.1080/0013191840360202

Tamir, Y. (2015). Teachers in the social trenches: Teaching civics in divided societies. Theory and Research in Education, 13(1), 121-136.

Vetenskapsrådet (2017). God forskningssed [Good research practice]. (Reviderad utgåva). Stockholm: Vetenskapsrådet.

Warnick, B. R., \& Smith, D. S. (2014). The controversy over controversies: A plea for flexibility and for "soft-directive” teaching. Educational Theory, 64(3), 227-244. https://doi.org/10.1111/edth.12059

Woolley, R. (2010). Tackling controversial issues in the primary school. Oxon: Routledge.

Zarkov, D. (2017). Populism, polarization and social justice activism. European Journal of Women's Studies, 24(3), 197-201. https://doi.org/10.1177/1350506817713439

Zembylas, M., \& Kambani, F. (2012). The teaching of controversial issues during elementarylevel history instruction: Greek-Cypriot teachers’ perceptions and emotions. Theory \& Research in Social Education, 40(2), 107-133. https://doi.org/10.1080/00933104.2012.670591 